\title{
Metode Pembelajaran Peer Teaching sebagai Solusi Dalam Pembelajaran Matamatika
}

\author{
Indra Joni ${ }^{1^{*}}$, Rian Vebrianto ${ }^{2}$, Zubaidah Amir $\mathrm{MZ}^{3}$ \\ 1,2,3 Magister Pendidikan Guru Madrasah Ibtidaiyah, Universitas Islam Negeri Sultan Syarif Kasim Riau
}

\begin{tabular}{l}
\hline \multicolumn{1}{c}{ INFO ARTIKEL } \\
\hline Riwayat Artikel: \\
Diterima: $12-07-2020$ \\
Disetujui: $24-09-2020$ \\
Diterbitkan: $01-10-2020$
\end{tabular}

Kata kunci:
Metode Pembelajaran
Peer Teaching
Pembelajaran Matematika
Motivasi Belajar
Hasil Belajar

\section{Alamat Korespondensi:}

Indra Joni

Program Studi Megister Pendidikan Guru Madrasah Ibtidaiyah

Universitas Islam Negeri Sultan Syarif Kasim Riau, Pekanbaru

E-mail: indra.joni@gmail.com

\begin{abstract}
This research is motivated by the implementation of basic education which is still very apprehensive, where teachers still use many old methods in teaching in class so that there is a lack of student involvement in the learning process. This has an effect on low student motivation. Therefore, this study aims to increase learning motivation and student learning outcomes using the Peer Teaching learning method as a solution in learning mathematics. The type of research used is a field study, namely interviews and literature research obtained from books or journals related to the main problem. The data collection technique is by interviewing homeroom teachers in grades V and VI and looking at the archive of test scores for the odd semester of the 2019/2020 school year. The analysis technique in this study used a qualitative descriptive analysis. Based on the literature reviews that the author conducted, it was found that many researchers have applied peer teaching learning methods at various levels of education starting from SD / MI, SMP / MTs and SMA / SMK levels can increase learning motivation and can also improve results. learn math students.
\end{abstract}

\begin{abstract}
Abstrak: Penelitian ini dilatarbelakangi oleh penyelenggaran pendidikan dasar masih sangat memprihatinkan, dimana guru masih banyak menggunakan metodemetode lama dalam mengajar dikelas sehingga kurangnya keterlibatan siswa dalam proses pembelajaran. Hal ini berpengaruh terhadap motivasi belajar siswa yang rendah Oleh karena itu, penelitian ini bertujuan untuk meningkatkan motivasi belajar dan hasil belajar siswa menggunakan metode pembelajaran Peer Teaching sebagai solusi dalam pembelajaran matamatika. Jenis penelitian yang digunakan adalah kajian lapangan yaitu dengan wawancara dan penelitian kepustakaan yang diperoleh dari buku atau jurnal-jurnal yang berhubungan dengan permasalahan utama. Adapun teknik pengumpulan data dengan cara wawancara dengan wali kelas V dan VI dan melihat arsip nilai ulangan semester ganjil tahun ajaran 2019/2020. Teknik analisis dalam penelitian ini menggunakan analisis deskriptif kualitatif. Berdasarkan kajian-kajian literatur yang penulis lakukan diperoleh informasi bahwa sudah banyak peneliti yang menerapkan metode pembelajaran tutor sebaya (peer teaching) diberbagai tingkatan pendidikan mulai dari tingkat $\mathrm{SD} / \mathrm{MI}, \mathrm{SMP} / \mathrm{MT}$ s dan SMA/SMK dapat meningkatkan motivasi belajar dan juga dapat meningkatkan hasil belajar matematika siswa.
\end{abstract}

\section{LATAR BELAKANG}

Indonesia adalah Negara yang sedang berkembang dalam berbagai sektor salah satunya bidang pendidikan. Pendidikan adalah salah satu program utama yang terencana dan berkesenambungan untuk membentuk kepribadian, kecerdasan, akhlak yang baik, serta keterampilan yang diperlukan oleh seseorang, masyarakat, nusa dan bangsa. Undang-undang Nomor 20 tahun 2003 pasal 1 ayat 1 pendidikan adalah usaha sadar dan terencana untuk mewujudkan suasana belajar dan proses pembelajaran agar peserta didik secara aktif mengembangkan potensi dirinya untuk memiliki kekuatan 
spiritual keagamaan, pengendalian diri, kepribadian, kecerdasan serta keterampilan yang diperlukan untuk dirinya, masyarakat, bangsa dan Negara. Dalam mewujudkan undang-undang tersebut, pemerintah membangun berbagai jenjang pendidikan formal salah satunya pendidikan dasar. Pendidikan dasar berbentuk Sekolah Dasar (SD) dan Madrasah Ibtidaiyah (MI) atau bentuk lain yang sederajat serta Sekolah Menengah Pertama (SMP) dan Madrasah Tsanawiyah (MTs), atau bentuk lain yang sederajat (UU RI No. 20 tahun 2003 pasal 17 ayat 2). SD/MI berlangsung selama 6 tahun yang bertujuan untuk menanamkan konsep dasar kepada anak, sehingga konsep-konsep yang diterima anak sebagai pembuka daya pikirnya dalam menghadapi jenjang pendidikan berikutnya yang lebih tinggi, sehingga terwujud masyarakat yang cerdas dan makmur.

Menurut Ali ada dua fungsi utama pendidikan dasar, yaitu: 1) melalui pendidikan dasar peserta didik dibekali kemampuan dasar yang terkait dengan kemampuan berpikir kritis, membaca, menulis, berhitung, penguasaan dasar-dasar untuk mempelajari saintek, dan kemampuan berkomunikasi yang merupakan tuntutan kemampuan minimal dalam kehidupan bermasyarakat; 2) pendidikan dasar memberikan dasar-dasar untuk mengikuti pendidikan pada jenjang pendidikan berikutnya. Lebih lanjut beliau menyatakan keberhasilan mengikuti pendidikan di sekolah menengah dan perguruan tinggi banyak dipengaruhi oleh keberhasilan dalam mengikuti pendidikan dasar (Ali, 2009). Hal ini menujukkan bahwa pendidikan dasar mempunyai peran yang sangat besar untuk kemajuan sumber daya manusia. Karena pentingnya pendidikan dasar dalam mempersiapkan karakter anak ke depannya (Sudaryanti, 2012), maka penyelenggaraannya tidak dapat dilakukan secara asal-asalan saja, akan tetapi perlu dilakukan berbagai cara untuk mewujudkannya.

Permendikbud No. 65 tahun 2013 bahwa proses pembelajaran pada satuan pendidikan diselenggarakan secara interaktif, inspiratif, menyenangkan, menantang, memotivasi siswa untuk berpartisipasi aktif, serta memberikan ruang yang cukup bagi prakarsa, kreativitas dan kemandirian sesuai bakat, minat dan perkembangan fisik serta psikologis siswa. Pada kenyataannya di lapangan penyelenggaran pendidikan dasar masih sangat memprihatinkan. Guru masih banyak menggunakan metode-metode lama dalam mengajar dikelas sehingga kurangnya keterlibatan siswa dalam proses pembelajaran. Hal ini berpengaruh terhadap motivasi belajar siswa yang rendah dalam setiap proses pembelajaran salah satunya pada mata pelajaran matematika. Sejalan dengan kesimpulan penelitian Ridha Sabrina, Fauzi dan M. Yamin menyatakan bahwa dalam proses pembelajaran guru lebih banyak menggunakan metode ceramah dan menjelas materi dengan menggunakan papan tulis sehingga siswa tidak termotivasi untuk belajar matematika dan bagi mereka pelajaran matematika sulit (Sabrina, et.al., 2017); (Thahir, M., \& MZ, Z. A., 2019); dan (Zein, et.al., 2019). Pertiwi menyatakan bahwa kegiatan pembelajaran tidak terlepas dari tiga komponen utama yaitu guru, siswa dan metode pembelajaran (Pertiwi, 2016). Oleh karena itu, seorang guru harus memilih motode yang sesuai dengan keadaan kelas atau siswa sehingga siswa merasa tertarik untuk mengikuti pelajaran yang diajarkan.

Berdasarkan permasalahan di atas, penulis tertarik meneliti suatu metode yang bisa diterapkan guru dikelas dengan tujuan bisa meningkatkan motivasi belajar dan hasil belajar siswa. Adapun metode yang akan penulis teliti adalah Metode Pembelajaran Tutor Sebaya (Peer Teaching) Sebagai Solusi dalam Pembelajaran Matamatika.

\section{METODE}

Penelitian ini bersifat kajian lapangan (field research) yaitu dengan wawancara dan penelitian kepustakaan (library research) diperoleh dari buku atau jurnal-jurnal yang berhubungan dengan permasalahan utama. Penelitian ini dilakukan dengan tujuan untuk mengetahui motivasi belajar siswa pada mata pelajaran matematika SDN 09 Kecamatan Bangun Purba, Kabupaten Rokan Hulu, Provinsi Riau dan menawarkan metode pembelajaran yang bisa diterapakan dalam proses pembelajaran. Adapun teknik pengumpulan data dengan cara wawancara dengan wali kelas $\mathrm{V}$ dan VI dan melihat arsip nilai ulangan semester ganjil tahun ajaran 2019/2020. Teknik analisis dalam penelitian ini menggunakan analisis deskriptif kualitatif. 


\section{HASIL DAN PEMBAHASAN}

\section{Hasil Belajar Siswa}

Berdasarkan hasil wawancara dengan wali kelas VA Ibu Masdeli, S.Pd dan VB Ibu Nuria Tama, S.Pd di SD Negeri 09 Kecamatan Bangun Purba yang dilaksankan pada tanggal 27 Januari 2020, guru menyampaikan bahwa siswa banyak yang tidak suka belajar matematika, motivasi belajarnya rendah dan kemampuan dalam menyampaikan ide atau gagasan juga masih sangat rendah. Ketika pembelajaran berlangsung peserta didik hanya mendengarkan guru menjelaskan dan peserta didik mencatat hal yang penting. Apa lagi siswa laki-laki lebih banyak bermain-main pada saat guru menjelaskan materi pelajaran dibanding siswa perempuan. Saat diberi tugas ulangan banyak siswa yang tidak serius dalam mengerjakannya masih banyak siswa mengalami kesulitan memahami materi mata pelajaran Matematika. Kemudian hasil wawancara dengan wali kelas mengemukakan bahwa hasil belajar Matematika kelas V di SD masih rendah. Adapun nilai ulangan siswa kelas VA SD Negeri 09 Kecamatan Bangun Purba, Kabupaten Rokan Hulu semester ganjil tahun ajaran 20190/2020 dapat dilihat pada tabel 1 di bawah ini:

Tabel 1. Hasil Ulangan Siswa Kelas VA Semester Ganjil Tahun Ajaran 2019/2020

\begin{tabular}{clccccccc}
\hline \multirow{2}{*}{ No } & \multirow{2}{*}{ Nama Siswa } & KKM & \multicolumn{7}{c}{ Nilai Ulangan } & Jumlah & Rataan \\
\cline { 5 - 7 } 1 & Adel Oktaviani & 75 & 76 & 75 & 79 & 77 & 307 & 76,75 \\
2 & Amir Abdad & 75 & 78 & 70 & 74 & 70 & 292 & 73,00 \\
3 & Diva Meissya & 75 & 75 & 80 & 78 & 77 & 310 & 77,50 \\
4 & Dimas Asril Pratama & 75 & 74 & 77 & 71 & 76 & 298 & 74,50 \\
5 & Hanan Kurniawan & 75 & 79 & 80 & 78 & 70 & 307 & 76,75 \\
6 & Heni Wijayanti & 75 & 75 & 75 & 73 & 71 & 294 & 73,50 \\
7 & Ilham Iskandar & 75 & 80 & 85 & 82 & 80 & 327 & 81,75 \\
8 & Djhpits Syahrikhan & 75 & 72 & 73 & 70 & 75 & 290 & 72,50 \\
9 & Lanna Sari & 75 & 80 & 80 & 79 & 80 & 319 & 79,75 \\
10 & Luna Zauna & 75 & 77 & 81 & 83 & 79 & 320 & 80,00 \\
11 & Lerpiana & 75 & 81 & 80 & 79 & 80 & 320 & 80,00 \\
12 & Nurul Aisyah & 75 & 75 & 78 & 77 & 75 & 305 & 76,25 \\
13 & Perdi Septihan & 75 & 79 & 80 & 79 & 80 & 318 & 79,50 \\
14 & Pasya Maulana & 75 & 77 & 75 & 74 & 79 & 305 & 76,25 \\
15 & Raya Sapitri & 75 & 70 & 80 & 79 & 72 & 301 & 75,25 \\
16 & Ramon Saputra & 75 & 75 & 85 & 80 & 78 & 318 & 79,50 \\
17 & Raju Kususma & 75 & 71 & 70 & 73 & 74 & 288 & 72,00 \\
18 & Reski Nanda & 75 & 80 & 80 & 79 & 80 & 319 & 79,75 \\
19 & Roy Saputra & 75 & 75 & 78 & 75 & 77 & 305 & 76,25 \\
20 & Salsa Bila & 75 & 73 & 75 & 73 & 73 & 294 & 73,50 \\
21 & Sifa Aunillah & 75 & 70 & 76 & 74 & 71 & 291 & 72,75 \\
22 & Syahdu & 75 & 71 & 76 & 74 & 70 & 291 & 72,75 \\
\hline & & & 1663 & 1709 & 1683 & 1664 & 6719 & 1679,75 \\
\hline & & & 75,59 & 77,68 & 76,50 & 75,64 & 305,41 & 76,35 \\
\hline
\end{tabular}

Sumber: Wali Kelas VA

Pada ulangan yang pertama sebanyak 7 siswa (31,82\%) yang mendapat nilai dibawah Kriteria Ketuntasan Minimal (KKM), ulangan kedua menurun menjadi 3 siswa (13,64\%), ulangan ketiga kembali meningkat 8 siswa (36,36\%) dan ulangan yang keempat terdapat 7 siswa (31,82\%) dari 22 siswa. Jika ditinjau dari rata-rata nilai per siswa dari empat kali ulangan tersebut terdapat 8 siswa (36,36\%) yang mendapat nilai di bawah Kriteria Ketuntasan Minimal (KMM) dan 14 siswa (63,64\%) yang 
72 Instructional Development Journal (IDJ), Vol. 3, No. 2, Agustus 2020, Hal. 69-74

memenuhi ketuntasan namun kategori nilai masih tergolong rendah. Hal yang sama juga terjadi pada siswa kelas VB semester ganjil tahun ajaran 2019/2020 dapat dilihat pada tabel 2 di bawah ini:

Tabel 2. Hasil Ulangan Siswa Kelas VB Semester Ganjil Tahun Ajaran 2019/2020

\begin{tabular}{|c|c|c|c|c|c|c|c|c|}
\hline \multirow{2}{*}{ No } & \multirow{2}{*}{ Nama Siswa } & \multirow{2}{*}{$\mathrm{KKM}$} & \multicolumn{4}{|c|}{ Nilai Ulangan } & \multirow{2}{*}{ Jumlah } & \multirow{2}{*}{ Rataan } \\
\hline & & & 1 & 2 & 3 & 4 & & \\
\hline 1 & Ahmad Sapei & 75 & 71 & 70 & 70 & 70 & 281 & 70,25 \\
\hline 2 & Alya Pinni & 75 & 77 & 80 & 78 & 70 & 305 & 76,25 \\
\hline 3 & Ahmad Sapei & 75 & 70 & 70 & 71 & 70 & 281 & 70,25 \\
\hline 4 & Alya Pinni & 75 & 79 & 80 & 78 & 70 & 307 & 76,75 \\
\hline 5 & Asrika Daulay & 75 & 70 & 75 & 73 & 71 & 289 & 72,25 \\
\hline 6 & Asshadran Al Zirazy & 75 & 80 & 85 & 82 & 80 & 327 & 81,75 \\
\hline 7 & Kurnia Sari & 75 & 70 & 73 & 70 & 75 & 288 & 72,00 \\
\hline 8 & Mifta Khoirani & 75 & 80 & 80 & 79 & 80 & 319 & 79,75 \\
\hline 9 & Mhd. Arkan Zaky & 75 & 83 & 85 & 83 & 80 & 331 & 82,75 \\
\hline 10 & Mustika Sari & 75 & 81 & 80 & 79 & 80 & 320 & 80,00 \\
\hline 11 & Ningsih & 75 & 73 & 78 & 77 & 70 & 298 & 74,50 \\
\hline 12 & Nur Khoyrani & 75 & 79 & 80 & 79 & 80 & 318 & 79,50 \\
\hline 13 & Nursaima Lubis & 75 & 72 & 75 & 74 & 70 & 291 & 72,75 \\
\hline 14 & Pangihutan & 75 & 70 & 80 & 79 & 72 & 301 & 75,25 \\
\hline 15 & Parhan & 75 & 75 & 85 & 80 & 78 & 318 & 79,50 \\
\hline 16 & Perdiansyah & 75 & 71 & 70 & 73 & 74 & 288 & 72,00 \\
\hline 17 & Randi Suhajud & 75 & 80 & 80 & 79 & 80 & 319 & 79,75 \\
\hline 18 & Rizaldi & 75 & 71 & 75 & 73 & 73 & 292 & 73,00 \\
\hline 19 & Sahdiman & 75 & 70 & 76 & 74 & 71 & 291 & 72,75 \\
\hline 20 & Tika Ramadani & 75 & 71 & 76 & 74 & 70 & 291 & 72,75 \\
\hline 21 & Yafi Fadhila & 75 & 82 & 85 & 85 & 80 & 332 & 83,00 \\
\hline 22 & Yunas & 75 & 70 & 76 & 70 & 70 & 286 & 71,50 \\
\hline 23 & Yutammin & 75 & 72 & 80 & 76 & 75 & 303 & 75,75 \\
\hline \multicolumn{3}{|c|}{ Jumlah } & 1717 & 1794 & 1756 & 1709 & 6976 & 1744 \\
\hline \multicolumn{3}{|c|}{ Rataan } & 74,65 & 78,00 & 76,35 & 74,30 & 303,30 & 75,83 \\
\hline
\end{tabular}

Sumber: Wali Kelas VB

Pada ulangan yang pertama sebanyak 13 siswa (56,52\%) yang mendapat nilai dibawah Kriteria Ketuntasan Minimal (KKM), ulangan kedua menurun menjadi 4 siswa (17,39\%), ulangan ketiga kembali meningkat 10 siswa (43,38\%) dan ulangan yang keempat terdapat 13 siswa (56,52\%) dari 23 siswa. Jika ditinjau dari rata-rata nilai per siswa dari empat kali ulangan tersebut terdapat 10 siswa (43,38\%) yang mendapat nilai dibawah Kriteria Ketuntasan Minimal (KMM) dan 13 siswa (56,52\%) yang memenuhi ketuntasan namun kategori nilai masih tergolong rendah.

Berdasarkan tabel 1 dan 2 dapat diambil kesimpulan bahwa hasil belajar Matematika masih rendah. Selain itu, berdasarkan nilai murni yang diperoleh dari hasil ulangan semester ganjil di kelas VA dan VB terjadi kesenjangan nilai diantara siswa yaitu ada yang mendapatkan nilai bagus dan ada yang mendapatkan nilai dibawah kriteria ketuntasan minimal (KKM). Hal ini disebabkan oleh pemahaman siswa berbeda-beda, ada sebagian siswa mudah memahami materi pelajaran yang disampaikan oleh guru dan ada sebagian lagi belum bisa memahaminya. Selain itu, hasil observasi peneliti guru masih menggunakan metode pembelajaran yang konvensional dan belum pernah menerapkan metode yang menarik dalam proses pembelajaran. Haryati Ahda Nst dan Nurdalilah menyatakan bahwa siswa dapat mencapai hasil belajar yang maksimal apabila seorang guru tepat dalam menerapkan metode pembelajaran (Ahda Nst \& Nurdalilah, 2019). Dari pemahaman siswa yang 
berbeda-beda diatas terdapat banyak potensi yang dapat dimanfaatkan dalam rangka menunjang keberhasilan suatu program pengajaran. Salah satu potensi yang dapat digali dan dimanfaatkan guru dalam proses pembelajaran adalah adanya beberapa siswa yang mempunyai kemampuan lebih dibanding dengan teman-temannya yang lain (Suparni, 2013). Mereka adalah kelompok siswa yang memiliki kemampuan lebih cepat dan mudah dalam memahami materi matematika yang telah diajarkan oleh guru. Selanjutnya mereka ini akan dimanfaatkan untuk membantu teman-temannya yang mengalami kesulitan dalam memahami suatu materi pelajaran dalam menangkap pelajaran, sehingga seluruh anggota kelas akan tuntas terhadap materi tertentu. Kelompok siswa inilah yang selanjutnya disebut sebagai Tutor Sebaya (Peer Teaching).

\section{Metode Pembelajaran Tutor Sebaya (Peer Teaching)}

Metode pembelajaran tutor sebaya (peer teaching) yaitu metode pembelajaran yang dilakukan dengan memberdayakan siswa yang memiliki daya serap yang tinggi dari kelompok siswa itu sendiri untuk menjadi tutor bagi teman-temannya, siswa yang menjadi tutor bertugas untuk memberikan materi belajar dan latihan kepada teman-temannya yang belum paham terhadap materi atau latihan yang diberikan guru dengan dilandasi aturan yang telah disepakati bersama dalam kelompok tersebut, sehingga akan terbangun suasana belajar kelompok yang kooperatif bukan kompetitif. Menurut Agus Mastrianto, Ali Imron dan Maskun model pembelajaran tutor sebaya (peer teaching) dilakukan dengan cara memberdayakan kemampuan siswa yang memiliki daya serap tinggi, siswa tersebut mengajarkan materi kepada teman-temannya yang belum paham sehingga memenuhi ketuntasan belajar semuanya (Mastrianto, et.al., 2017). Sani menyatakan bahwa model pembelajaran tutor sebaya (peer teaching) merupakan model pembelajaran yang melibatkan teman sebaya dengan kemampuan di atas rata-rata kelas sebagai tutor untuk teman-teman di kelasnya (Sani, 2013). Selain itu, hubungan teman umumnya lebih dekat dibandingkan dengan hubungan guru dengan peserta didik, sehingga peran teman mendukung adanya suatu motivasi tersendiri bagi siswa.

Berdasarkan hasil penelitian Pangerti menunjukkan bahwa metode pembelajaran tutor sebaya (peer teaching) memiliki pengaruh yang signifikan terhadap motivasi belajar (Pangerti, 2015). Hastari juga menyimpulkan dari hasil penelitiannya bahwa penerapan model tutor sebaya dapat memberikan motivasi dan mendorong peserta didik menjadi aktif dalam proses pembelajaran sehingga peserta didik tidak hanya diam, mencatat, dan mendengarkan ceramah dari guru, melainkan peserta didik akan terlibat secara aktif dalam proses pembelajaran bersama dengan tutor dan anggota lain dalam kelompoknya (Hastari, 2019). Asmi, Herawati dan Thaher juga melaporkan hasil penelitiannya bahwa pembelajaran tutor sebaya (peer teching) dapat meningkatkan motivasi belajar dan juga dapat meningkatkan hasil belajar matematika siswa Sekolah Dasar (Asmi, et.al., ). Selain motivasi dari teman akan menambah kepercayaan diri dan juga akan meningkatkan kemampuan komunikasi menyampaikan ide atau gagasan.

\section{SIMPULAN DAN SARAN Simpulan}

Siswa kelas VA dan VB SD Negeri 09 Kecamatan Bangun Purba, Kabupaten Rokan Hulu banyak yang tidak suka belajar matematika, motivasi belajarnya rendah dan kemampuan dalam menyampaikan ide atau gagasan juga masih sangat rendah. Metode pembelajaran yang diterapkan masih konvensional dan belum pernah menerapkan metode yang lain. Hasil belajar matematika siswa banyak yang dibawah kriteria ketuntasan minimal. Metode yang baik diterapkan dalam proses pembelajaran Metode pembelajaran tutor sebaya (peer teaching). Sudah banyak peneliti yang menerapkan metode pembelajaran tutor sebaya (peer teaching) diberbagai tingkatan pendidikan mulai dari tingkat SD/MI, SMP/MTs dan SMA/SMK dapat meningkatkan motivasi belajar dan juga dapat meningkatkan hasil belajar matematika siswa. 


\section{Saran}

Saran peneliti kepada guru sebaiknya mencoba menggunakan metode pembelajaran tutor sebaya (peer teaching) dalam mata pelajaran Matematika sebagai variasi dalam mengajar dan guru hendaknya selalu memberikan motivasi terhadap siswa agar lebih bersemangat dalam belajar dan tidak merasa jenuh ketika belajar.

\section{DAFTAR RUJUKAN}

Ali, M. (2009). Pendidikan untuk Pembangunan Nasional: Menuju Bangsa Indonesia yang Mandiri dan Berdaya Saing Tinggi. Jakarta: Grasindo.

Asmi, P., L., Herawati, S., Thaher, A. (2018). Program Peningkatan Motivasi dan Hasil Belajar Matematika dengan Menggunakan Metode Tutor Sebaya Pada Siswa Kelas VI A SD Pertiwi 2 Padang. Universitas Bung Hatta.

Haryati Ahda Nst, N. (2019, February). Implementasi Metode Tutor Sebaya terhadap Pembelajaran Matematika. In Prosiding Seminar Nasional Hasil Penelitian (Vol. 2, No. 1, pp. 447-453).

Hastari, R. C. (2019). Penerapan Strategi Tutor Sebaya dalam Meningkatkan Motivasi Belajar Matematika. Abdimas: Jurnal Pengabdian Masyarakat Universitas Merdeka Malang, 4(1), 46-50.

Mastrianto, A., Imron, A., \& Maskun, M. (2017). Efektivitas penggunaan model pembelajaran tutor sebaya untuk meningkatkan minat belajar siswa. PESAGI (Jurnal Pendidikan Dan Penelitian Sejarah), 5(8).

Pangerti, B. (2015). Pengaruh Metode Pembelajaran Tutor Sebaya Terhadap Motivasi Belajar, Minat Belajar dan Hasil Belajar Matematika Kelas XI Ilmu Alam MAN Model Sorong. Jurnal Ilmu Pendidikan Indonesia, 3(1), 30-39.

Pertiwi, A. (2016). Pengaruh Metode Pembelajaran Tutor Sebaya terhadap Efikasi Diri dan Hasil Belajar Matematika Siswa Kelas VIII SMP Negeri 24 Makasar.

Sabrina, R., Fauzi, F., \& Yamin, M. Y. M. (2017). Faktor-Faktor Penyebab Rendahnya Motivasi Belajar Siswa dalam Proses Pembelajaran Matematika di Kelas V Sd Negeri Garot Geuceu Aceh Besar. Jurnal Ilmiah Mahasiswa Pendidikan Guru Sekolah Dasar, 2(4).

Sani, R. A. (2013). Inovasi pembelajaran. Jakarta: Bumi Aksara.

Sudaryanti, S. (2012). Pentingnya pendidikan karakter bagi anak usia dini. Jurnal Pendidikan Anak, 1(1).

Suparni, S. (2013). Pembelajaran Tutor Sebaya Implikasinya terhadap Pembelajaran Matematika (Studi Kasus pada Prodi TMM STAIN Padangsidimpuan). Logaritma: Jurnal Ilmu-ilmu Pendidikan dan Sains, 1(02).

Thahir, M., \& MZ, Z. A. (2019). Pemahaman Konsep Matematika Melalui Pendekatan Reciprocal Teaching Pada Siswa Kelas X MAN Kuala Enok. Instructional Development Journal, 2(1), 1-5.

Zein, M., Nuh, Z. M., Dardiri, D., Jasril, J., Candra, R. M., Hanafi, I., \& Thahir, M. (2019). Hybrid Learning in Mathematics Learning: Experimental Study in SMA Negeri 1 Pekanbaru. Malikussaleh Journal of Mathematics Learning (MJML), 2(2), 56-60. 